\title{
Historicizing the Networks of Ecology and Culture: Eleanor Anne Porden and Nineteenth-Century Climate Change
}

In 1818, the poet Eleanor Anne Porden wrote and published The Arctic Expeditions. The poem is a paean to one of the first of the polar expeditions that would come to dominate ideas of British national pride in the nineteenth century. As an early literary response to the race to Arctic, it was also an early textual construction of global climate change, as I intend to show. Today, however, The Arctic Expeditions is often consigned to footnotes in historical considerations of polar exploration and the climatic conditions that prompted it, and has been overshadowed by the Arctic visions of its immediate contemporary, Mary Shelley's Frankenstein (1818). Yet, compared with Shelley's novel, Porden's poem opens up just as effectively and, one might argue, engages more directly with the intricate complex of ecological events and cultural productions that constituted Britain's fascination with Arctic spaces in the nineteenth century. This complex was comprised of the meteorological phenomena and climatic shifts that facilitated scientific discovery and exploration as well as the socio-political rhetoric and controversy that seemed so imbricated in them from the start. Porden's poem functions as a useful index to this network of the ecological and the discursive, even as it participates within that network.

The overall aim of this essay is to place Porden's poem within its historical— that is to say, its ecological and cultural—context. The Arctic Expeditions was written in direct response to an influential essay on Arctic exploration, now known to be the work of the second secretary of the Admiralty, John Barrow, a man who was instrumental in setting up Britain's forays into polar exploration. These Arctic voyages were facilitated not just by Barrow's rousingly jingoistic statements but by something much more fortuitous - an unprecedented degree of polar ice-melt in the early nineteenth century. This in turn was part of global climatic instability, an after-effect of the eruption of Mount Tambora in what is now 
Indonesia and related, therefore, to the notorious "year without a summer" that was 1816 , which also played such a part in Shelley's writing of Frankenstein. In the first section of my essay, I trace Barrow's article to whalers' reports of ice-melt, in order to demonstrate the shifts in emphasis that Barrow introduced to the eyewitness accounts.

I turn then to Porden's poem, which, like Barrow's article, is no simple reflection of these ecological and cultural conditions but, rather, an intervention of sorts. However, unlike Barrow's conservative rhetoric and the equally political counter-arguments from left-leaning rivals (and unlike, too, the radical views held by Shelley and identified by readings of Frankenstein), Porden's poem expresses an idealized — some might say naïve — trust in science and its relationship with the environment as distinctly uncontaminated by political machination (though not national interest more broadly defined). Porden's poem is worth recontextualizing not just within the ideological milieu represented by Barrow, but also within the purview of Porden's scientific connections - namely, the Royal Institution in London, which Porden claimed as her intellectual home - and alongside her other, more overtly scientific poems. Any historicized understanding of a text must account for the interlaced cultural and ecological conditions under which it was written and published. By focusing on Porden's text, too, I hope not merely to demonstrate the extent to which textual and climatic — and other natural—events are networked, but to enable an understanding, via a particular instance, of the significant role that a given node must play within that network. All must be kept in view in a truly historicized analysis of texts and their ecological and cultural contexts.

In this, my essay aligns itself with other recent projects that treat textual history in terms of ecological and cultural history. In 2008, Gillen D’Arcy Wood called for a historical turn in ecocriticism. In the introduction to a special issue of The Journal for Early Modern Studies provocatively named "Eco-historicism," Wood suggests that eco-historicism would 
"explain, in a way no other discipline yet fully does, what the hard data of historical climatology meant in cultural terms, in the minds and lived experience of people" $(2$, original emphasis). Combining "quantitative data" with "qualitative sources" such as "poems, diaries, newspapers, paintings, folklore" (4), eco-historicism would study "climate and environment as objects of knowledge and desire, analyzed through 'thick' description of specific episodes of ecological micro-contact" (1). Wood's reference to "thick" description recalls the new historicism of Stephen Greenblatt and others; in particular, it references Clifford Geertz's ethnographic techniques, the exemplar for the new historicist practice of describing the minutiae of historical context very much as an anthropologist would observe and describe the ins and outs of a remote and utterly unknown culture (3-31). What Wood has in mind, it would seem, is an analysis of an ecological event and the cultural response it prompts as they express themselves in a range of typically "new historicist" sources: anecdotes, marginal or unofficial writings, visual representations, maps, and sketches, for example.

In response to Wood, and bearing in mind the insights of theorists such as Bruno Latour (25-26), I would suggest that not just the "qualitative" but the "quantitative" must be thought of as a mediation of an ecological event or object - although those quantitative acts of mediation are carried out with the aim of objectivity and a view towards increasingly standardised expectations. That is to say, the historical ecological event will be known to us through some scientific measurement (whether contemporary to the event or to us) or discursively (usually contemporary to the event), and all such data are constructed, to differing extents. Thus, eco-historicism, in my reading, is not a matter of ascertaining what "the hard data of historical climatology meant in cultural terms," as Wood puts it, but of realizing that the "hard data" are also the result of a process of cultural meaning-making, albeit of a different sort from those with overtly narrative or lyrical intentions (2). In this regard, Wood's analysis of the Tambora eruption and the response of the British 
administration in Java led by Stamford Raffles all too readily sets reported accounts of the eruption on one side and Raffles's revisionist colonialist ideals, as expressed in his History of Java (1817), on the other (“The Volcano Lover" 33-55). In comparison, Robert Markley, putting forward a version of eco-historicism in the same issue as Wood's essays that he labels "eco-cultural materialism" (104), is at pains to read the violent storm that lashed southern England and Wales in November 1703 through the lens of Daniel Defoe's journalistic account The Storm (1704), eyewitness reports, and twenty-first-century climate historians' reconstructions of the local impacts of the Little Ice Age, all the while keeping in mind the varying contingencies that underpin all these accounts. In sympathy with Markley, I would venture that a "thick" description of ecology and culture should be a description of the ways in which climatological circumstances are experienced through textual responses and the cultural attitudes to which they give rise. This is not to say that climatic events are merely constructed, but that a simple distinction between ecological event and textual response ignores the extents to which they are entangled. It ignores just how much we owe to the textualized processes of measurement and quantification in order to make sense of climate and other natural phenomena.

In tracing the links that draw together Porden's poem, Barrow's writings, and the Tambora eruption, it becomes apparent that any encounter with the originary ecological event (if such an event can ever be "originary") becomes, very quickly, a material-discursive entanglement and that no such encounter is, strictly speaking, "objective.” For Markley, Defoe's rendering of the storm serves to remind us that "we are the inheritors of assumptions and values about 'man,' 'nature,' and 'stewardship' that are still hedged in by eighteenthcentury conceptions" (120), as well as alerting us to the pre-modern lifestyle to which we may have to return if we are unable to wean ourselves off our fossil-fuel addictions. I propose here that Porden's and Barrow's interpretations of Arctic ice-melt brought on by Tambora, as 
mediated encounters with the natural, may not offer us any lessons about how to live with "nature," but they do offer us just as valuable lessons about how all such encounters are mediated. ${ }^{1}$

\section{The 1818 Polar Controversy}

In 1818, the Quarterly Review published an article whose effect on the reading public, according to one historian of the periodical, was "electric" (Cameron 145). The Quarterly was the leading conservative periodical of the time, established by publisher John Murray as a response to the dominance of Whiggish periodicals, particularly the Edinburgh Review. Although the review had been published anonymously (as most of the periodical's reviews were), many knew it had been written by John Barrow (Shine and Shine 59), the Quarterly's most prolific reviewer (Wheatley 467). Only nominally a review (again, this was the case with most of the periodical's reviews), the piece was really an extended essay on a subject close to the author's heart—changes in climatic conditions in the North Pole and the promise this held out for Arctic exploration. Indeed, the article was, in many ways, a puff piece for the first of such expeditions, the twin voyages of John Ross and David Buchan to Greenland and Spitzbergen, respectively. It sold 12,000 copies on the day it was published (Cutmore; Wood, Tambora 129), and by Barrow's own account years later, was thought by Murray himself to have “very much increased" the Quarterly's circulation (Auto-biographical Memoir 505). ${ }^{2}$ The article set off a heated debate primarily between the Quarterly Review and the Edinburgh Review — what Siobhan Carroll terms "the 1818 polar controversy" (212) — on the costs and benefits of polar exploration, the devotion of British resources and manpower to the cause, and the veracity of the climatic changes that Barrow was trumpeting. The article was one of eighteen pieces on Arctic voyaging written by Barrow for the Quarterly between 1816 and 1840, among the two hundred or so he wrote for the Quarterly throughout his career. ${ }^{3}$ 
Together with his Chronological History of Voyages into the Arctic Regions (1818), these articles comprise what Adriana Craciun has labeled the "Murray polar print nexus" (440).

Barrow was a man whose broad experiences and interests encompassed science, exploration, and commerce. In addition to being second secretary of the Admiralty, he had been secretary to various embassies to China and South Africa and was co-founder of the Royal Geographical Society and an influential member of the Royal Society; he had even tried his hand at sailing with a whaling ship as a teenager (Lloyd 1-19). ${ }^{4}$ As a prolific contributor to the Quarterly, he was able to use his articles to promote whatever aspect of Britain's political and trade interests in which he was involved, whether imperial aspirations in Africa or the consolidation of naval supremacy (Cavell, Tracing the Connected Narrative 55-56). ${ }^{5}$ From 1816, Barrow began his efforts to garner public backing for a string of Arctic expeditions. Barrow's position in the Admiralty and his influence at the Royal Societyparticularly with its president, Joseph Banks - meant that he could secure the ships and men for such endeavors in the name of both national and scientific interest. Popular support, gained through the press, oiled the wheels of Barrow's efforts. Certainly, he was remarkably successful: he was responsible for the fifteen or so expeditions sent by the Admiralty to the Arctic between 1818 and 1845, and is regarded by some, such as Fergus Fleming, as "the father of Arctic exploration" (11). ${ }^{6}$

The main objective of these early voyages was, it would seem, to discover the Northwest Passage or an open and unfrozen sea at the North Pole, or both at once. However, the question of Barrow's underlying motivations deserves some attention. For Barrow, the search for the Northwest Passage seems to have been, in part, about proving some of his long-held scientific hypotheses about what lay at the Pole. Indeed, the debate that raged between Barrow and his rival John Leslie, writing for the Edinburgh Review, dealt with this and the essentially meteorological question of whether climate conditions in the Arctic were 
changing (Carroll 212). ${ }^{7}$ And yet, Barrow's career first in service to diplomatic missions abroad and then in shaping Britain's admiralty must be accounted for. The scientific gains to be had from Arctic discovery dovetailed with the benefits of opening up commercial and naval opportunities for Britain. These, and the need to redeploy servicemen made redundant by the end of the Napoleonic wars, weighed heavily on Barrow's Arctic interests (Fleming 12). Moreover, a reading of Barrow's article, with its quick dismissal of science and its emphasis on exploration as an end in itself, suggests that other factors mattered just as much; as Wheatley puts it, he "can never entirely let go of a possible commercial payoff” (469). For Barrow, science enabled exploration; exploration in turn could lead to maritime influence and trade.

In other words, the February 1818 article was an important early salvo in Barrow's Arctic efforts; it offered, as Wood puts it, "a sweeping scientific and historical rationale for the government-funded polar enterprise" (Tambora 129). Barrow would himself assert in his memoirs that the article "and the extraordinary facts therein stated [...] gave rise also to the recent Arctic voyages, by sea and by land, that have added so largely to the geography and scientific discoveries, made in those regions" (Auto-biographical Memoir 505). The article launches Barrow's argument by beginning with a powerful description of the recent ice-melt: Among the changes and vicissitudes to which the physical constitution of our globe is perpetually subject, one of the most extraordinary, and from which the most interesting and important results may be anticipated, appears to have taken place in the course of the last two or three years, and is still in operation. (199) Then, without elaborating further, Barrow switches tack to the poignant story of the handful of communities on the east coast of Greenland, descended from Eric the Red, that had settled from Scandinavia in the tenth century but lost contact with the outside world in the fifteenth century when the glaciation of the Little Ice Age blocked all passage to Greenland. Barrow 
states that it is "generally admitted that, for the last four hundred years, an extensive portion of the eastern coast of Old Greenland has been shut up by an impenetrable barrier of ice, and, with it, the ill-fated Norwegian or Danish colonies, which had been established there" (200). It is only after a considerable explication of the situation in Greenland that he reveals that the "extraordinary change" (200) in the natural environment is nothing less than "the disappearance of the whole, or greater part of this vast barrier of ice" (200). That is, the tale of so-called "lost Greenland” (200; original emphasis) packs Barrow's argument with a punch, a human-interest angle, before he refers the reader to climatic transformations taking place at the pole. Halfway through his article, Barrow recaps, enumerating what the melting of Arctic sea ice would enable. "First," is the "influence which the removal of so large a body of ice may have on our own climate"; then comes "the opportunity it affords of inquiring into the fate of the long-lost colony on the eastern coast of Old Greenland" (204). Barrow's final reason directs the reader, after much circumlocution, to the issue of the Northwest passage: "Thirdly, the facility it offers of correcting the very defective geography of the arctic regions in our western hemisphere; of attempting the circumnavigation of Greenland, a direct passage over the pole, and the more circuitous one along the northern coast of America, into the Pacific" (204).

Barrow goes on to devote the entire second half of his article to a disquisition on that third object: the investigation of the possibility of a Northwest Passage and of an open Arctic sea that would allow traffic over the pole. It is by the end of the article that the commercial importance of this primary objective becomes obvious. In his final paragraph, he lobbies hard for changes to the Whale Fisheries Act 1776, which provided what he saw as an inadequate reward for discovering the Northwest Passage, and to the Custom House Oath, which rendered "the encouragement meant to be given by the legislature [...] a complete nullity" by requiring that "the master and ship's company shall proceed and use their utmost endeavours 
to take whales, or other large creatures, living in the seas, and on no other design or view of profit" (223, original emphasis; see also Jackson, “Three Puzzles” 3-5). For Barrow, such amendments would allow ships to break off from whaling activities where necessary and to assist in the discovery of either the Northwest Passage or the North Pole, therefore increasing the chances of a breakthrough to establish these key maritime routes. These, then, are Barrow's priorities for the 1818 expedition. There is no mention of lost Greenland at this point.

Barrow does not completely marginalize the scientific phenomenon that he so deftly exploits. He brings a substantial amount of evidence to bear on his claims of the loss of Arctic sea ice. Carroll, in critiquing Barrow's article for exploiting questions of polar ice levels for the possibilities that ice-melt held for Arctic exploration, disregards the crucial point that Barrow had seized on the matter of ice-melt not merely because it suited him but because he had found evidence to suggest that it was indeed taking place (217-18). Barrow cites a string of reports, from ship captains sailing in the vicinity of Halifax and Newfoundland, of "islands of ice" (200) and "detached ice-bergs, from a hundred to a hundred and thirty feet above the surface of the water" (200). Most importantly of all, however, he mentions one whaling captain in particular, William Scoresby the Younger, in a passage worth quoting at length:

[W]e have the direct testimony of Mr. Scoresby the younger, a very intelligent navigator of the Greenland seas, for the disappearance of an immense quantity of arctic ice. In a letter to Sir Joseph Banks, he says, "I observed on my last voyage (1817) about two thousand square leagues (18,000 square miles) of the surface of the Greenland seas, included between the parallels $74^{\circ}$ and $80^{\circ}$, perfectly void of ice, all of which has disappeared within the last two years". And he further states, that though on former voyages he had very rarely been able to penetrate the ice, between the 
latitude of $76^{\circ}$ and $80^{\circ}$, so far to the west as the meridian of Greenwich, "on his last voyage he twice reached the longitude of 10 west;" that in the parallel of $74^{\circ}$, he approached the coast of Old Greenland; that there was little ice near the land; and adding "that there could be had a justifiable motive for navigating an unknown sea at so late a season of the year". He also found the sea so clear in returning to the southward, that he actually landed on Jan Mayen's island, which is usually surrounded with a barrier of ice, and brought away specimens of the rocks. (202) Scoresby certainly was a reliable eyewitness. An experienced whaler who had completed his first voyage to Arctic waters in 1800 at the age of eleven, he also made and recorded detailed observations of the meteorology, ecology and geography of the Arctic (Jackson, Introduction i-xxxvii). He and his whaling journals may have been mercilessly caricatured in Moby Dick (Melville 134 and 159-160; see also Dameron 98), but his records were recognized as profound contributions to polar exploration by Banks and, to a lesser extent, Barrow, just as they are now by his biographers (Preston; Stamp and Stamp). Perhaps, if anything, it is Scoresby's letter to Banks that should be acknowledged as the catalyst for the Arctic expeditions of 1818 and after. Scoresby had, for several years, corresponded with Banks, providing him with scientific measurements and observations. He wrote the letter in October 1817 in the hopes of commanding an expedition of his own, explicitly expressing a wish to examine and survey the islands of East Greenland or Spitzbergen, especially the eastern part, which has not been visited [for] many years past; and to ascertain, for the benefit of the whalers, whether the whales resort thither; to endeavour to reach the shore of West Greenland, determine its position, prove its insularity, and ascertain the fate of the Icelandic colony together with making researches $[\ldots]$ relative to the northeast and north-west passages, \&c. (qtd. in Scoresby-Jackson 124-25) 
It is worth noting that Scoresby wished simply to "make researches" toward, and not specifically to discover, the existence of Northwest and Northeast Passages. The letter drew a positive response from Banks. When Banks showed it to Barrow, the latter was almost instantly galvanized, acting quickly through the Admiralty to organize two expeditions, each with two ships, captains and crews, to take advantage of the situation. Barrow gave command of the twin expeditions to naval officers Ross and Buchan respectively, offering Scoresby the role of master on one of the ships. Scoresby, deeply offended, refused (Jackson, Introduction $\mathrm{xxX}-\mathrm{xxxv})$.

There is evidence other than Scoresby's of early nineteenth-century polar ice-melt. It is now well established that the melting ice was, paradoxically, part of the cold and miserable "year without a summer" of 1816, the cause of which was the 1815 eruption of Mount Tambora. Carroll reads the British experience of low temperatures and sunless days as one of the causes for scepticism towards Barrow's claims of ice-melt and its propitiousness for Arctic exploration. Yet, modern-day meteorological consensus is that the ash-fall from volcanic eruptions such as Tambora results not just in temperate and equatorial cooling but also in significant Arctic warming (Schneider et al). ${ }^{8}$ Wood's recent cultural history of the eruption offers a thorough analysis of its effects, what he calls the "Tambora climate emergency of 1815-18" (Tambora 8). Wood notes elsewhere that "the most explosive volcanic eruption in the historical record" caused unseasonably low temperatures and violent weather events from China to Europe as well as "volcanic winter warming between 1815 and 1818 [that] melted the Arctic icepack, prompting the first race of nations to the North Pole" (“1816, The Year without a Summer" 3). In other words, Tambora brought about both a cooling in the temperate and equatorial zones (which Barrow erroneously attributed to the presence of icebergs so far southward) and the warming and melting of Arctic sea ice. 
Somewhat perversely, Barrow contrasted the phenomenon of gradual Arctic ice-melt with the suddenness of a seismic shift:

The convulsion of an earthquake and the eruption of a volcano force themselves into notice by the dismay and devastation with which, in a greater or less degree, they are almost always attended: but the event to which we allude has been so quietly accomplished, that it might have remained unknown, but for an extraordinary change which a few intelligent navigators remarked in the state of the arctic ice, and the reports of the unusual quantities of this ice observed in the Atlantic. (199-200) Yet, the ice-melt, gradual as it may have seemed to Barrow, had indeed begun with a seismological event. Climate change had happened as the result of a very dramatic and specific episode, after which, in Wood's words, the world returned, "just as suddenly, to its prior relative equilibrium” (“1816, The Year without a Summer”3).

In reading Barrow's article, one cannot help but be struck by how his interests in climatic questions extend little beyond their usefulness in opening up Arctic exploration. Despite the nods he makes to scientific matters, he very easily, as Wood puts it, "throws up his hands" (Tambora 131). He does, one must grant, point to the "influence which the removal of so large a body of ice may have on our own climate" as a worthwhile object of investigation alongside a discovery of the Northwest Passage and polar sea. Yet, the weight placed in his article on considering the former is insignificant compared to the pages devoted to the latter. Indeed, in a brief paragraph, Barrow notes simply that in our present ignorance of the immediate cause, we must be satisfied to ascribe the revolution that has taken place to the decree of Providence, who, as Paley observes, "is the author of infinitely various expedients for infinitely various ends;" to consider it as the result of one of those prospective contrivances, which are appointed to correct the anomalies, and adjust the perturbations of the universe. (204) 
As Janice Cavell reminds us, Barrow began writing about Arctic exploration in his fifties, and she contends that his scientific leanings belonged to an earlier, providential generation (Tracing the Connected Narrative 54). Certainly, his invocation here, via William Paley, of the theological "watch-maker's analogy" - that a design implies a designer - turns what had been a potentially controversial scientific issue into a settled matter of faith. One suspects this is in order to move on to the material (that is, economic) problem of the existence of a passage around the pole. By way of contrast, it is worth remembering that Scoresby's writings indicate that he was interested mainly in the possibilities for whaling and the significance of mapping the Arctic seaways for the purposes of "making researches." Banks recognized in his letter to the Admiralty that Scoresby's observations signaled that a considerable change of climate, inexplicable at present to us, must have taken place in the circumpolar regions by which the severity of the cold, that has for centuries enclosed the seas in the high northern latitudes in an impenetrable barrier of ice, has been, during the last two years, greatly abated. (qtd. in Jackson, Introduction xxix)

This change may be "considerable"" but it is also "inexplicable," and Banks is not tempted to muse any further on its causes. Given Barrow's influence with Banks, there is speculation amongst Arctic historians that this letter, which carries much of the phrasing that Barrow employed in his Quarterly article, was actually written by Barrow (Lloyd 124). ${ }^{9}$ Certainly, one can see that Barrow went only a little further than this in his article, proclaiming merely the "extraordinary" nature of this climatic shift.

\section{Contextualizing The Arctic Expeditions}

To trace the ecological event from its eruption to its global climatic impact on to the emergence of these in Arctic rhetoric - that is, to record the links that tie Scoresby to Banks 
to Barrow to Porden - is to become aware of how readily available the scientific observations of Tambora's impact were to diverse political and social uses. Particularly for my purposes, these links conspire to show that Barrow and Porden employed the climatic conditions brought about by Tambora to different ends.

Porden was inspired to write The Arctic Expeditions on the $31^{\text {st }}$ of March 1818, the day after she had visited the two ships of John Ross's expedition to the Arctic, the Isabella and Alexander, at Deptford in London; the idea for that visit had been planted by Barrow's article. In her preface, she asserts that both the idea of polar exploration and the lost Greenland colony "are subjects on which for some years my mind has dwelt with peculiar interest" (5). Crucially, however, "this feeling was again excited when I heard of the great revolution in the Polar Seas, which made it probable that the one might be reached, and the fate of the other ascertained" (5). The source of this information was Barrow's "very able and delightful article in the last Quarterly Review" (5-6). Appearing in Number 35 of the journal, it was dated October 1817 but actually appeared in mid-February 1818 (many of the Quarterly's issues were published late [Cameron 146]). ${ }^{10}$ It therefore appeared just a month and a half before Porden visited Deptford and wrote her poem.

At the time the poem was composed and published, Porden, aged twenty-two, was a poet of modest fame. As the daughter of the eminent and well-connected architect William Porden, she had gained the kind of scientific and cultural education and enjoyed the kind of access to publishing avenues that would have been denied many women. From the age of thirteen, she had been encouraged by her father to run an informal literary salon from their home and to attend the Royal Institution's public lectures on chemistry and geology; both experiences led directly to the composition of a scientific romance, The Veils (1815), written when she was fifteen and appearing when she was twenty. This poem and The Arctic Expeditions were published by John Murray, with whom her father had a passing 
acquaintance; some other poems appeared in the Quarterly. Cavell reveals that The Veils made such a loss that William Porden paid Murray $£ 84.4 s$ to cover publication costs ("Miss Porden" 84). And yet, whatever one makes of the many privileges which Porden enjoyed, one must consider that they at least allowed her to place herself - and to imagine a world in which other women could be placed too- on a footing with men of science and letters.

The poem begins with a rousing call to the men of the Isabella and Alexander to sail for British glory — to "Britain's trident plant in seas unknown" (line 4)—and for science"leave, by Science led, your native land" (line 20). It invokes two muses, eschewing the familiar figures of myth to apostrophize a feminized North Star and another "unseen Directress" (line 13), identified in a footnote as the personification of magnetism. It then moves swiftly on to what Porden, after Barrow, sees as another chief objective of the expedition, to discover the fate of lost Greenland, inaccessible for four hundred years- "Four times the sun his hundred courses ran" (line 29)—in which "Each winter piled increasing glaciers round" (line 37). At last, says the poem of what one is now able to read as the glaciation of the Little Ice Age, the "barrier bursts" (line 55). In a vignette of what could provocatively be called global climate change, the poem goes on to describe how Arctic icemelt now means that vast icebergs are free to float southwards to freeze the Iberian and African coasts (again echoing one of Barrow's suppositions, initially put forward to counter ice-melt sceptics who had pointed to the sub-average temperatures brought on by Tambora):

But lo! the barrier bursts, on distant seas

Those floating winters chill the sultry breeze;

Vast piles of ice, now bright with heavenly blue,

Now tinged by setting suns with flamy hue,

Southward they sail, and Gades' vine-clad coast,

And burning Afric feel the unwonted frost. (lines 55-60) 
A repetition of that key alliterative phrase - the "barrier bursts" - underlines this climatic shift as a chance for Britain to discover the lost colony or its remnants: "The barrier burstsand Britain, first of all / Wherever perils threat, or duties call, / Sends forth her heroes" (lines 61-63). The poem further sketches an idyllic picture of lost Greenland found:

Again their light canoes shall sail, again

Shall milder Summers rear their golden grain:

Nay, long by frosts opprest,-—our happier clime

Again shall hail returning Summer's prime;

Its ruddy grapes shall lavish Autumn bring,

And all Sicilia's sweets adorn the Spring. (lines 71-76)

The retreating ice simultaneously heralds the chance for the rediscovered Greenlanders to sail forth again and bodes a new warmer climate for Britain, all the while enabling the exercise of British naval heroics.

The rest of the poem serves to emphasize the poem's central theme-the privileging of fact over fancy. The very next section of the poem insists: "No day-dreams these of Bard's fantastic brain" (line 77). Throughout the poem, the veracity of these poetic visions is shored up by countless footnotes citing observations (mainly those reported in the Quarterly). The poem then exhorts the explorers to stay courageous not against "Strange fancies" but in the face of "real ills" (line 91). These include extreme cold and snow blindness to debris-ridden icebergs to the effects of the magnetic pole on ships' compasses and the difficulty of telling time from a sun that never sets during an Arctic summer:

The flickering compass points with fitful force,

And not a star in heaven directs your course,

But the broad sun, through all the endless day, Wheels changeless round, sole beacon of your way... (lines 108-111) 
In a no-nonsense footnote, Porden briskly clarifies the risk brought on by the midnight sun: "Towards the middle of the polar day of six months, the sun must continue for some weeks nearly at the same elevation, and the time of course can be estimated only by his easterly or westerly position" (16). Just as they will face "real ills" rather than imagined ones, Ross's ships will return with recorded observations that will redress the impartial information gleaned from previous travelers' tales. So, for example, the poet imagines stories of the Kraken now properly verified by the explorers' experiences. The former is of the kind that "late we smiled to hear, / When drest by fancy, and enlarged by fear" (lines 160-161); the latter will be underwritten by science. Importantly, Porden literally underwrites this idea with a footnote that refers us to several suitably empirical observations: "The sea snake, cast on shore on the Orkneys in 1808, and the still more gigantic animal of the same kind which made its appearance near Boston in America last summer [...] make it probable that some animal, in part answering [Erik Pontopiddan's] description of the Kraken, may be found in the Polar basin" (20). Significantly, Barrow's articles would go on to be criticized for alluding to romance and hence for being unscientific (Carroll 211-12), but Porden exploits such generic regulations. By reversing the tactic and injecting scientific observation into her poem, she presents her imaginings as rational, accurate, and somehow superior to mere poetry, those "daydreams" that dare to emerge without verification and citation from the "Bard's fantastic brain." Porden distinguishes her scientific poetry from this by aligning her work with the reports to come from the Ross expedition.

Thus, the explorers - those men of science - and the poet - that woman of lettersare on comparable missions: both are marrying heroic venture with scientific data (which in this case begins with the observation of climatic instability). The conclusion of the poem and its final pages — which are, crucially, not the same thing — serve to drive this point home. The poem ends on a triumphant note, construing the voyagers as representatives of Britannia- 
“Queen of the Seas!'” (line 200) — and vanquishers of a personified North Pole, a notably masculinized "Genius of the North" (line 196). Not only does this gendered battle pointedly place the expedition under the aegis of a feminized Britain, it works by thought association to return the reader to the poem's two other personifications, the twin muses who commence the poem - the goddess of the North Star and the female personification of magnetic power. This point is established typographically too: these last emphatic lines lead directly into the volume's final pages and thus to the lengthy scientific note in which Porden explains magnetic power. This report takes up six pages of the poem's octavo volume, and is, in many ways, the poem's true conclusion, since it brings home so much of the poem's subtext. Porden begins by declaring, "One of the objects of the Arctic Expedition is to discover the North Magnetic Pole" (25), and then goes on to enable the reader to discover the magnetic pole through her very able explication. Porden then explains the anomalies in polar magnetism, by juxtaposing those observed and reported by the explorer Matthew Flinders on his Australasian voyages with the findings disseminated by the Royal Institution physicist John Millington:

These circumstances, so necessary to be generally known, have hitherto been confined to Captain Flinders' narrative [...] till they were detailed in a popular form by Professor Millington, in his highly interesting course on Magnetism, just concluded at the Royal Institution. (29)

Of course, it is Porden, with her personal experience of these lectures, who is on hand to translate Millington's ideas to her reader. The (female) poet and (male) explorer are thus both readily identifiable as facilitators of scientific knowledge.

My interpretation of the gender-neutral heroic claims Porden makes for herself here and elsewhere run counter to the conclusions reached by other readers of her poetry. In an overall compelling analysis of the nationalistic strains of Porden's poem, Jen Hill suggests 
that Porden assumes a feminized, domesticated, brand of heroism for herself, one that complements the macho derring-do of the explorers:

If the well-documented Admiralty-sponsored polar expeditions of 1818 invited a kind of national participation-by-proxy by civilians who followed their preparations in the newspapers, Porden used their departure as an opportunity to write women into maleonly heroic narratives of Arctic exploration [...] by claiming women's authorship for the production of Arctic narrative and thus in its larger project of national identity building. (69)

Hill similarly reads Porden's juxtaposition of her poetry with the explorers' tales as one that "champions narrative as the real production of Arctic exploration" (85), and thus as a gesture that reinforces her position as a domestic muse. Such a reading, however, fails to account for Porden's code-switching throughout the poem between two voices - the poet's and the scientist's — as she moves from verse narrative to scientific note. Indeed, Porden had achieved a similar effect in the much longer and more overtly scientific Veils. Hill rightly focuses on that poem's "tension between the spaces of rationality and irrationality" (71) and locates this not just in the narrative's complex allegories but in the contrast between this and the "radically divergent diction in the footnotes, where Porden cites authoritative sources ranging from [...] Humphrey [sic] Davy to Roget” (71). Yet, Hill does not identify the extent to which Porden assumed the right to speak with and for this community of scientists, and the way in which her prefatory identification of herself as a "pupil of the Royal Institution" (The Veils vii) works hard to grant her this right (Johns-Putra 37-38). In this regard, Porden's argument with her then fiancé, the explorer John Franklin, over her decision to maintain a literary career must be read as a strenuous effort on her part to establish her writing not as a domestic complement to his very public career as a naval commander and explorer but as a counterpart to his scientific endeavors. In addition to the letters exchanged during this 
quarrel, it is worth reading an earlier set of the couple's correspondence, namely the exchange on his second voyage in which Porden updated him on the latest discoveries in electro-magnetism, for these helpfully reveal her attempts to position herself as Franklin's potential partner in science (Porden, letter to Franklin, 23 May 1821; Franklin, letter to Porden, 2 October 1821).

In all, the climatic changes that Barrow appropriated to the ends of the British Admiralty are here pressed idealistically into the service of science. For Porden, it was the explorer's job to help observe and the scientist's role (as well as hers) to explain wideranging climatic variations and local atmospheric conditions. Her disquisition on magnetism ends with her musings on how best to construct an Arctic experiment that would use the Aurora Borealis to understand better the connection between magnetism and electricity. Certainly, Porden's rhetoric is not disinterested insofar as it was embedded in a nationalistic ideal, that is to say, it insists that British explorers and scientists would lead the way in building the world's knowledge. Yet, it speaks more of the objectivity of the emerging ideals of the Royal Institution, whose aim of "the application of Science to the common Purposes of Life" (qtd. in Frank 1) was explicitly stated at its foundation in 1799, and less of the political and economic ambitions of Barrow, the Admiralty, and the Quarterly.

Porden's vision of nineteenth-century climate change-like any "vision" of climate change and, indeed, like any literary environmental construct — was developed through a complex political and discursive matrix. This involves not just the ecological event of the Tambora eruption or the data around the Arctic ice melt it induced but the many rhetorical twists and turns so quickly taken by the ecological event, its impacts, and the measurements of those impacts. Neither Porden nor Barrow could have anticipated that the Arctic campaign would last long into the century, beyond the effects of Tambora, and, indeed, that it would 
end with the tragic death of Porden's husband. Barrow and Porden were to become intricately linked through John (later Sir John) Franklin. He had been captain of one of the four ships of the 1818 expedition — the Trent, part of the Spitzbergen expedition under Buchan's overall command. The publication of The Arctic Expeditions led to Franklin's request to be introduced to the poet when he returned in 1819 (Cavell, Tracing the Connected Narrative 64; Woodward 156). When they met, Franklin, having been granted full command of his own expedition by Barrow, was shortly to depart on his second Arctic voyage. With a long and perilous journey ahead of him, Franklin possibly thought it unfair to Porden to progress to any formal understanding, but — as she would later write — when he left, "[he] carried a large share of [her] heart with [him]" (Letter to Franklin, 21 May 1823). On that voyage, he mapped and named the Porden Islands in the Canadian Arctic Archipelago (Franklin, letter to Porden, 2 October 1822). He returned in October 1822. They were married less than a year later and their daughter was born in 1824. Porden died a week after Franklin departed for his third Arctic expedition in February 1825, having urged him to go despite her worsening health from tuberculosis. Thus, it was only two months after her death that, in the middle of writing a letter to her from America, he received the news that she was dead (Beardsley 121). However, it is Franklin's tragic fourth Arctic expedition of 1845 for which he is best remembered and to which is occasionally (and erroneously) attributed Barrow's long-soughtfor goal— the discovery of the Northwest Passage. The search for Franklin carried out by his second wife, Lady Jane, lasted over three decades and cost more men than the expedition itself. This ill-fated expedition was not just the end for Franklin; the protracted and ultimately unproductive rescue mission exhausted public interest and spelled the end too for the British Admiralty's voyages to the Arctic (MacLaren 35-36).

Britain's nineteenth-century missions to the Arctic began in the 1810s as much with the phenomenon of a global climate system response to volcanic eruption as with Barrow's 
and the Quarterly's public relations campaign, girded by the poetic idealism of writers such as Porden; it concluded with Franklin's fatal voyage and the equally vexed rhetorical battles played out in the wake of this failure. The expeditions, both in their beginnings and in their trajectory as a whole, amply demonstrate how such ostensibly "cultural" histories are made up not just of ecological encounters but of so many discursive entanglements.

\section{Notes}

${ }^{1}$ I should note that this essay may be read as building on Wood's recent cultural history of Tambora, Tambora: The Eruption that Changed the World, which provides a detailed account of the eruption's material and discursive effects but only makes brief mention of Porden's poem (144). Wood's book appeared as this essay was undergoing final revisions for publication.

${ }^{2}$ Fleming states that "a review from Barrow could add 1000 to the Quarterly's subscription list - an 8 per cent increase on circulation" (87-88).

${ }^{3}$ Fleming lists the number of Barrow's reviews as 195 (8); Wheatley states that Barrow wrote "over 200 articles" (466) for the Quarterly.

${ }^{4}$ As Wheatley points out, however, Barrow kept his practical experience of Arctic seas out of public knowledge, preferring to present himself as an academic expert of polar exploration (468).

${ }^{5}$ Lloyd remarks, "From whatever angle one looks at the history of his times, whether it be the state of the Navy when Britannia really ruled the waves, or the discovery of the Niger, or the North West passage, Barrow's figure appears in the background, planning, advising, promoting" (11). See also Wood's comment that "Barrow, the most powerful bureaucrat at the Admiralty in the post-Napoleonic period, used the pages of the widely read Quarterly Review to advance his policy agenda for Britain's navy" (Tambora 124).

${ }^{6}$ As Cavell suggests, "If any individual can be held responsible for the course British Arctic exploration took in the first half of the nineteenth century, that individual was surely John Barrow" (Tracing the Connected Narrative 55).

${ }^{7}$ Carroll disregards the trenchant politics of the Quarterly's exchanges with the Edinburgh Review in order to read this contest as primarily a debate about "climate change" the context of concerns that had emerged earlier in the century about increasing rather than receding Arctic ice (213-219).

${ }^{8}$ While the build-up of Arctic ice around Greenland might be attributed to the onset of the Little Ice Age, the receding of such ice does not easily coincide with the end of the Little Ice Age. Certainly, recent scientific data, including studies of ice-cores in Greenland, show that cold temperatures continued in the Arctic at least until the 1850s; see, for example, Fischer et $a l$ and Behringer.

${ }^{9}$ Lloyd states that "Banks was now so crippled with gout that he could hardly write at all" (124). 
${ }^{10}$ As Cavell comments, the 1817 dating of the article has led to mis-readings of Frankenstein, which appeared in January 1818, as written in response to Barrow's article ("Miss Porden" 201. n46). This misapprehension occurs in Richard and is repeated by Hill (56-57). Moreover, it should be noted that the Quarterly's notoriously damning review of Frankenstein (written by John Wilson Croker, the First Secretary of the Admiralty and therefore Barrow's superior) actually appears in the issue immediately following the issue containing Barrow's article. 


\section{Works Cited}

Barrow, John. An Auto-Biographical Memoir of Sir John Barrow, Bart., Late of the Admiralty; Including Reflections, Observations, and Reminiscences at Home and Abroad, from Early Life to Advanced Age. London: John Murray, 1847. Print.

[Barrow, John.] "On the Polar Ice and the Northern Passage into the Pacific" (Rev. of Narrative of a Voyage to Hudson's Bay by Lieutenant Chappell). Quarterly Review 18.35 (Oct 1817): 199-223. Print.

Beardsley, Martyn. Deadly Winter: The Life of Sir John Franklin. London: Chatham, 2007. Print.

Behringer, Wolfgang. A Cultural History of Climate. Trans. Patrick Camiller. Cambridge: Polity Press, 2010. Print.

Cameron, J. M. R. "John Barrow, the Quarterly Review's Imperial Reviewer." Conservatism and the Quarterly Review. Ed. Jonathan Cutmore. London: Pickering and Chatto, 2007. 133-150. Print.

Carroll, Siobhan. "Crusades against Frost: Frankenstein, Polar Ice, and Climate Change in 1818." European Romantic Review 24:2 (2013): 211-230. Print.

Cavell, Janice. "Miss Porden, Mrs. Franklin, and the Arctic Expeditions: Eleanor Anne Porden and the Construction of Arctic Heroism (1818-25)." Arctic Exploration in the Nineteenth Century: Discovering the Northwest Passage. Ed. Frédéric Regard. London: Pickering and Chatto, 2013. 79-94. Print.

Cavell, Janice. Tracing the Connected Narrative: Arctic Exploration in British Print Culture 1818-1860. Toronto: University of Toronto Press, 2008. Print.

Craciun, Adriana. "Writing the Disaster: Franklin and Frankenstein." Nineteenth-Century Literature 65.4 (2011): 433-480. Print.

[Croker, John Wilson.] Review of Frankenstein, or the Modern Prometheus. Quarterly Review 19.36 (January 1818): 379-385. Print.

Cutmore, Jonathan. "Quarterly Review Archive: Volume 18, Number 35." Romantic Circles. University of Maryland. February 2005. Web. 31 March 2014.

Dameron, J. Lasley. "Melville and Scoresby on Whiteness." English Studies 74.1 (1993): 96104. Print.

Geertz, Clifford. "Thick Description toward an Interpretive Theory of Culture." The Interpretation of Cultures. New York: Basic Books, 1973. 3-31. Print.

Fischer, H., M. Werner, D. Wagenbach, M. Schwager, T. Thorsteinnson, F. Wilhelms, J. Kipfstuhl, and S. Sommer."Little Ice Age Clearly Recorded in Northern Greenland Ice Cores." Geophysical Research Letters 25 (1998): 1749-52. Print.

Fleming, Fergus. Barrow's Boys. London: Granta, 1998. Print.

Franklin, John. Letter to Eleanor Anne Porden. Hudson's Bay, Ship Prince of Wales, Atlantic Ocean. 2 October 1822. MS. D3311/8/1/15. Derbyshire Record Office, Matlock.

Hill, Jen. White Horizon: The Arctic in the Nineteenth-Century British Imagination. Albany: State University of New York Press, 2008. Print.

Jackson, C. Ian. Introduction. The Arctic Whaling Journals of William Scoresby the Younger. Vol. 3: The Voyages of 1817, 1818 and 1820. London: Hakluyt Society, 2009. i-xxx vii. Print.

Jackson, C. Ian. "Three Puzzles from Nineteenth Century Arctic Exploration.” The Northern Mariner/Le marin du nord 17.3 (2007): 1-17. Print.

James, Frank A. F. L. Introduction. "The Common Purposes of Life": Science and Society at the Royal Institution of Great Britain. Ed. Frank A. F. L. James. Aldershot: Ashgate, 2002. 1-16. Print. 
Johns-Putra, Adeline. "Blending Science with Literature": The Royal Institution, Eleanor Anne Porden, and The Veils.' Nineteenth-Century Contexts 33.1 (2011): 35-52. Print.

Latour, Bruno. "Drawing Things Together." Representation in Scientific Practice. Ed.

Michael Lynch and Steve Woolgar. Cambridge, MA: MIT Press, 1990. 19-68. Print.

Lloyd, Christopher. Mr. Barrow of the Admiralty: A Life of Sir John Barrow 1764-1848. London: Collins, 1970. Print.

MacLaren, I. S. "John Barrow's Darling Project (1816-46)." Arctic Exploration in the Nineteenth Century: Discovering the Northwest Passage. Ed. Frédéric Regard. London: Pickering and Chatto, 2013. 19-36. Print.

Markley, Robert. "'Casualties and Disasters': Defoe and the Interpretation of Climatic Instability." The Journal for Early Modern Studies 8 (2008): 102-124. Print.

Melville, Herman. 1851. Moby Dick. Ed. Tony Tanner. Oxford: Oxford University Press, 2008. Print.

Porden, Miss [Eleanor Anne]. The Arctic Expeditions: A Poem. London: John Murray, 1818. Print.

Porden, Miss [Eleanor Anne]. The Veils; or The Triumph of Constancy. London: John Murray, 1815. Print.

Porden, Eleanor Anne. Letter to John Franklin. 23 May 1821. MS. D3311/8/1/5, Derbyshire Record Office, Matlock.

Porden, Eleanor Anne. Letter to John Franklin. 21 May 1823. MS. D3311/8/3/12, Derbyshire Record Office, Matlock.

Preston, Clarence. William Scoresby, 1760-1829: Whitby's Most Successful Whaler. Whitby: Whitby Literary and Philosophical Society, 1964. Print.

Richard, Jessica. “'A Paradise of My Own Creation': Frankenstein and the Improbable Romance of Polar Exploration.” Nineteenth-Century Contexts 25:4 (2003): 295-314. Print.

Schneider, David P., Caspar M. Ammann, Bette L. Otto-Bliesner, and Darrell S. Kaufman. "Climate Response to Large, High-latitude and Low-latitude Volcanic Eruptions in the Community Climate System Model." Journal of Geophysical Research: Atmospheres 114 (2009), D15. Web.

Scoresby-Jackson, R. E. The Life of William Scoresby. 1861. Cambridge: Cambridge University Press, 2011. Print.

Shine, Hill and Helen C. Shine. The Quarterly Review under Gifford: Identification of Contributors 1809-1824. Chapel Hill: University of North Carolina Press, 1949. Print.

Stamp, Tom and Cordelia Stamp. William Scoresby, Arctic Scientist. Whitby: Caedmon, 1976. Print.

Wheatley, Kim. "The Arctic in the Quarterly Review." European Romantic Review 20:4 (2009): 465-490. Print.

Wood, Gillen D'Arcy. "1816: The Year without a Summer.” BRANCH: Britain, Representation and Nineteenth-Century History. Ed. Dino Franco Felluga. Extension of Romanticism and Victorianism on the Net. Web. 9 August 2013.

Wood, Gillen D'Arcy. "Eco-historicism." The Journal for Early Modern Studies 8 (2008): 17. Print.

Wood, Gillen D'Arcy. Tambora: The Eruption that Changed the World. Princeton: Princeton University Press, 2014. Print.

Wood, Gillen D'Arcy. "The Volcano Lover: Climate, Colonialism, and the Slave Trade in Raffles's History of Java (1817)." The Journal for Early Modern Studies 8 (2008): 33 55. Print. 